\title{
Albanian National Museums: How to Overcome the Digital Gap Towards a Better National Heritage Promotion
}

\begin{abstract}
Aurora Kamberi
PhD Cand., University of Tirana, Faculty of History \& Philology, Development Program Units for Tangible Heritage, Ministry of Culture. Albania
\end{abstract}

\section{Abstract}

The digital and IT technologies are shaping the essential functions in our society where even the traditional culture heritage institutions such as museums are looking forward to figuring out the way to use a great range of possibilities for better promotion and visibility. The paper aims to set out the main issues that must be addressed if we consider to have a comprehensive understanding of the opportunities for a new perspective on Albania's digitalized museums, as one of the most important cultural heritage institutions. Currently, the Albanian national museum network accounts for 14 museums of different typologies which are situated across the country, with a total of outdoors and in store collections of objects and artifacts. As of now, most Albanian museums have an online presence, with a variety of online information, however the paper seeks to interlink the promoting cultural heritage variables of museums using IT tools not merely to reproduce existing objects, but to actualize new ones through an interactive and educative environment. Since the digitalization of museums is a task that has combined efforts, budgets, and research by assessing the national culture policy of Albania, the paper also aims to explore the opportunities that may be taken in consideration by the policy - makers and museum managers in the country.

Keywords: Albania, national museums, oovercome, digital gap, national heritage promotion

\section{Introduction}

\section{Digitalization \& on-line accessibility of museums: A short approach overview}

We are living in a world that digitalization is part of our human experience, even the museums are getting ready to meet the challenges and opportunities of such technology information. The potential of technology to present museum collections in new and important ways now seems limitless. In early 1990s, CD-ROMs and later the Internet played an important role, it showed citizens the view of various 
museum's collections of the world. The development of technology brought about its evolution. With one foot in museum education and the other in research, online access to museum collections now takes various forms: from image and static text (for visitors in general), detailed catalogs (for researchers), virtual tours to real spaces and exhibitions online.

The digitalization of museums is viewed as one of the main challenges as Navarrete stated, technology and the development of the internet will increase the promotion and the representation of artists (for example, the Van Gogh Museum in Amsterdam), while museums with less well-known works struggle to display their online collections to communicate with (potential) customers (Navarrete, 2020).

World-famous museums are facing a new approach, which provides visitors the opportunity to visit their collections by going online. The Guggenheim Museum of Modern Art has a large database with various works of art from the Guggenheim permanent collection. It includes more than 1,700 works by about 625 artists from the Guggenheim General Permanent Collection. It offers the possibility of exploration through 2 features like work and browse, within the art can be found only in the form of text and image. The opposite happens with the Louvre Museum which offers a complete database of its collection from different areas of the museum.

Each has a unique structure according to the type of object. Scholars who visit Louvre Museum have access to the museum archives, to boxes of supplementary materials for each object, not all found online but included in the bibliography. Louvre Museum offers a full 3-D view of its space, as well as some creative web features as the Google Art lets you explore some of the world's largest museums with a street view technology. Meanwhile the Virtual Museum of Canada, opened in 2001, is considered as an only space and software that presents many museums in Canada and offers them a system through which they can upload virtual exhibits. The development of technology in the art-history sphere is changing tourists' environments and attitudes.

Most of them get engaged in a circular way flowing by a pre-trip information to trip memories. How can cultural tourists get engaged through digitalization? Researchers and museum managers claim that digitalization can be achieved in collaboration with other museums as Clough stated "....... Today's digital revolution is providing a dizzying array of tools that offer opportunities for learning institutions all over the world to become more vibrant and accessible. This revolution provides the means to share vital information, enabling people to learn more, shape informed opinions, and make decisions in their daily lives (Clough, 2013).

The presentation of a whole sector and the collection of art works creates the possibility for more access and creative use by tourists. Digitalized collections and creative content can be curated to suit specific tourism interests linked to museum locations across countries. By promoting and sharing this content in partnership with a range of publishers, it can reach the target groups of cultural tourists through their most common channels of use. In that framework the Smithsonian Institute Museum 
Network in US makes a relevant effort as'Clough (2013) noted that "Within the Smithsonian, some of our museums have been pacesetters in adopting digital technology; as early as the 1970s our National Museum of Natural History began to digitize selected natural history specimens, and the Smithsonian American Art Museum developed the first searchable database of American art. But not until 2009 did the Smithsonian develop a pan-Institutional approach, taking a hard look at prioritizing the 137 million objects to be digitized. Plans include a "charter collection" of objects to be rendered in 3-D, a technology that will allow objects to be viewed in ways not possible when on display in a museum setting.

The collection facility has been explored by Europeana (Nauta \& Wietske, 2015), an accessible online platform for millions of books, paintings, films, museum objects and archival records across Europe. As the only site offering access to Europe's cultural heritage, Europeana (2015) provides access to culture for all, including education, work, and leisure, and serves as a hub for the creative industries and innovative reuse of cultural material. With the help of technology, it turns Europe's cultural heritage into a sustainable asset for its citizens and economy. Given this, digitalizing, accessing, and preserving it for future generations is one of the challenges of the Digital Agenda for Europe (EU, 2011). At EU Member State level, the EU Commission encourages policy debate and brings together stakeholders to improve online presence and digital preservation through the Commission Recommendation on the 27 October on the Digitalization and Internet Access of Cultural Material and Digital Preservation 2011 by stating that "...The Digital Agenda for Europe seeks to optimize the benefits of information technologies for economic growth, job creation and the quality of life of European citizens, as part of the Europe 2020 strategy. The digitization and preservation of Europe's cultural memory which includes print (books, journals, and newspapers), photographs, museum objects, archival documents, sound and audiovisual material, monuments and archaeological sites (hereinafter 'cultural material') is one of the key areas tackled by the Digital Agenda (European Commission. 2011).

At the same time, it has monitored the progress towards the implementation of the Commission Recommendations and facilitated the exchange of information and good practices of Member States, 'policies and strategies through the Member States' Group on Digital Digitization and Preservation (MSEG). Despite its importance, sometimes the main point remains digitalization long-term sustainability. In addition to the positive aspects, there are reasons to avoid its implementation. First, not every collection can be present online. The possibility of digitalization of all museums is almost impossible according to experts view. Usually, projects that have been successful implemented require an evaluation of the museum collection by offering only the most important items. Another complex issue that they face is the copyright infringement that strongly impacts the selection of materials as stated in this report: 'One of the key challenges of museum digitalization is the so-called "the digitization of copyrighted works found in museum collections, e.g., the creation of a digital copy of a work, which will most often be created through photography, scan or a similar mean 
(Bandle. et al, 2020) Many cultural heritage institutions have chosen to avoid the complexities of copyright law by digitalizing materials that have passed into the public domain and are no longer covered by copyright restrictions.

According to the International Council of Museums (2017), "The museum is a nonprofit institution, its main mission is to serve the society and its development, open to the public, which appropriates, preserves, communicates, and exhibits the tangible and intangible heritage of humanity and education, study and leisure purposes. The words "in the service of society and its development" are relevant to the modern museum, which has redefined its mission as a populist mission, including locals and foreigners, young and old. Given that the main goal of museums is to provide everyone with access to their information through as many channels as possible, the focus is on quantity, by reaching as many visitors as possible, offering the largest number of interpretive and educational tools (analog and digital) and presenting the largest amount of information. The Internet offers the ideal medium to accomplish all of this, and as a result museum have begun to transform their websites, online access, and digitization of collections into a tool that is shaping the future.

Methodology: This is a qualitative study, based on document analysis in which documents are reviewed and interpreted to set out the main issues that must be addressed if we consider to have a comprehensive understanding of the opportunities for a new perspective on Albania's digitalized museums, as one of the most important cultural heritage institutions.

\section{Albania digital gap with museums: How can Albania improve the heritage} promotion Albania has been described as country that offers tourists and locals alike a plethora of museums which celebrate the nation's finest craftsman and artists, while also delving into its history. Albania national museum network account of 21 museums of different typologies which are situated in the coastal and no - coastal area of Albania. Pursuant to Law No. 272018 dated 17.05.2018 on Cultural Heritage that has been recently approved and the classification it has made for museums, the National Network of Albanian Museums consists of 21 museums according to such typology 1) 13 are museums whose collections are preserved in specific buildings (museum buildings) of which some are reclassified as central museums under the subordination of national museums 2) 8 are Open-Air Museums where with under this name are classified the National Archaeological Parks across over Albania. The Albanian national network of museums consists of thirteen buildings which are situated across the country as follow: Tirana (3), Durres (1), Kruja (2), Korca (3), Berat(2), Vlora (1) Shkoder (1) together with eight open air museums or the so-called National Archaeological Parks (Butrinti, Finiq, Antigonea, Amantia, Orikumi, Bylis, Apolonia, Lezha, Shkodra). On the other hand, there are also even twelve other local museums which are under the administration of local governments but with a low level of promotion, on-line accessibility, and visitors. Given that the largest number of tourists arriving in Albania are concentrated in the coastal areas (Durres, Vlora, 
Saranda, Lezha, Shkodra) the figures shows that nine out of twenty one national museum or approximately $43 \%$ of them are located there respectively in Durres (1) Shkoder(3) Vlore(3), Lezha (1) and Saranda(1). which apparently looks a satisfactory figure. However, these national museums still have a lot to do and serving as main attractions for culture tourism in Albania. Since the last percentage of tourist spent their holiday along the coastal line cities of Albania is needed a better link with the blue and culture tourism by transforming museums of these area to the most attracted sights where tourist can enjoy the national heritage objects. In that framework, the level of digitalization of museum collections across Albania Network of National Museums and especially the ways how use all forms of communication and online promotion remain a key challenge.

Tab I. The official website addressees, Facebook, and Instagram accounts of Albania National Museums Network (ANMN) used so far to disseminate online information to visitors

- N/A - Non Applicable (there is no official website address or social media accounts)

\begin{tabular}{|c|c|c|}
\hline $\mathrm{Nr}$ & $\begin{array}{l}\text { Name of } \\
\text { Museum }\end{array}$ & Website \\
\hline 1 & $\begin{array}{l}\text { National } \\
\text { History } \\
\text { Museum } \\
\text { (NHM)- Tiranë }\end{array}$ & $\begin{array}{l}\text { http://www.mh } \\
\text { k.gov.al/ }\end{array}$ \\
\hline 2 & $\begin{array}{l}\text { National Art } \\
\text { Gallery - } \\
\text { Tiranë }\end{array}$ & $\begin{array}{l}\text { http://www.gal } \\
\text { eriakombetare. } \\
\text { gov.al }\end{array}$ \\
\hline & $\begin{array}{l}\text { National } \\
\text { Museum of } \\
\text { Communist } \\
\text { Period } \\
\text { Wiretapping: } \\
\text { "House of } \\
\text { Leaves"- } \\
\text { Tiranë }\end{array}$ & $\begin{array}{l}\text { http://muzeugj } \\
\text { ethi.gov.al/ }\end{array}$ \\
\hline 4 & $\begin{array}{l}\text { National } \\
\text { Archeological } \\
\text { Museum- } \\
\text { Durrës }\end{array}$ & $\mathrm{N} / \mathrm{A}$ \\
\hline
\end{tabular}

Facebook Instagram

https://www.faceb ook.com/MuzeuHis torikKombetar/

https://www.faceb ook.com/GaleriaKo mbetareArteve/

https://www.faceb ook.com/muzeugje thi/

https://www.faceb ook.com/muzeuark eologjikdurres/ https://www.inst agram.com/muze ukombetar/

https://www.inst agram.com/galeri akombetareartev e/

https://www.inst agram.com/muze ukombetarshtepi amegjethe/

https://www.inst agram.com/muze u_arkeologjik_dur res/ 
$5 \quad$ National

Museum

"Gjergj

Kastrioti" -

Krujë

6 National

Ethnographic

Museum-

Krujë

7 National

Photography

Museum, “

Marubi"

Shkodër

8 National

Iconographic

Museum

"Onufri" Berat

9 National

Ethnographic

Museum-

Berat

10 National

Museum of

Medieval Art-

Korcë

11 National

Education

Museum-

Korcë

12 National

Archeological

Museum-

Korcë

13 National

Independence

Museum- Vlorë http://muzeum

et-kruje.com

http://muzeum

et-kruje.com

https://www.m arubi.gov.al/

https://muzeu met-berat.al/

https://muzeu met-berat.al/

http://www.mu zeumesjetar.gov .al/

$\mathrm{N} / \mathrm{A}$

https://muzeua rkeologjik.word press.com/

$\mathrm{N} / / \mathrm{A}$

https://www.faceb ook.com/Muzeu-

Kombetar-i-

Pavaresise-Vlore-

742203565793714

/ ook.com/arkeologji akorce/ https://www.inst agram.com/muze umetkruje/

https://www.inst agram.com/muze umetkruje/

https://www.inst agram.com/maru bimuseum/

https://www.inst agram.com/p/Br SkqKTgp62/?hl=e $\mathrm{n}$

https://www.inst agram.com/p/Br SkqKTgp62/?hl=e $\mathrm{n}$

https://www.inst agram.com/muze umesjetar/

https://www.inst agram.com/muze u_kombetar_i_arsi mit_korce/

N/A

https://www.inst agram.com/explo re/locations/339 232756/muzeukombetar-ipavaresise-vlore/ 
14 National

Archeological

Park- Butrint(

Open Air

Museum)-

Sarandë

15 National

Archeological

Park- Finiq(

Open Air

Museum)-

Sarandë

16 National

Archeological

Park -

Antigone(

Open Air

Museum)-

Gjirokastër

17 National

Archeological

Park- Amantial

Open Air

Museum_)-

Vlorë

18 National

Archeological

Park -

Oriku(Open

Air Museum)-

Vlorë

19 National

Archaeological

Park-Bylis(

Open Air

Museum) -Fier

20 National

Archaeological

Park- Apoloni(

Open Air

Museum) - Fier

21 National

Archeological-

Lezhë( Open

Air Museum)

\section{https://www.b}

utrint.al/

N/A

N/A

https://www.faceb

ook.com/people/Pa

rku-Arkeologjik-

Antigone/1000095

22445233/

$\mathrm{N} / \mathrm{A}$

N/A

N/A

N/A

$\mathrm{N} / \mathrm{A}$

https://www.faceb

$\mathrm{N} / \mathrm{A}$

$\mathrm{N} / \mathrm{A}$ https://www.faceb ook.com/ByllisArch aeology/

https://www.faceb ook.com/parkuark eologjikapolonia.ap olonia

$\mathrm{N} / \mathrm{A}$ ook.com/ParkuKo mbetarButrint

$\mathrm{N} / \mathrm{A}$

https://www.inst

agram.com/explo

re/locations/995

504380/parku-

kombetar-i-

butrintit/

$\mathrm{N} / \mathrm{A}$

https://www.inst agram.com/explo re/locations/495 916775/parkuarkeologjikantigone/?hl=en

N/A

N/A

https://www.inst agram.com/parku arkeologjikapolon ibylis /

https://www.inst agram.com/parku arkeologjikapolon ibylis/

N/A 


$$
\begin{aligned}
& \text { National } \\
& \text { Archeological } \\
& \text { Park- Shkodër } \\
& \text { (Open Air } \\
& \text { Museum) }
\end{aligned}
$$
N/A

N/A

N/A

It should be noted that Albania is still in the early stages of the process of digitalizing museum collections and various forms of promoting museum information online using social networks such as Facebook. Instagram. Out of 21 museums throughout Albania, 11 of them or 51\% (See Tab 1), including all National Archaeological Parks that are considered open-air museums, do not have an official website where they can present all their information in Albanian. English for local and foreign visitors, but they do it mainly through social networking accounts on Facebook or Instagram. It is a challenge that needs to be addressed through a pro-active approach from the point of view of policies in the field of museum management, so that information about museum collections and their features can be easily accessed among groups of interest.

Furthermore, the national network of museums in Albania is overcoming such obstacles through a series of initiatives funded by international donors. The Onufri Museum of Berat is the first national museum that offers a virtual tour through digital means. Visitors can experience a virtual experience through a multi-lingual audio guide. Aside from the fact that this tour offers a meaningful experience, it also offers equal opportunity for everyone wherever they are located. Onufri National Museum is noted to be the best solution... '... for making the first step into embracing new art technology that translates the one-dimensional experience into a full audio-visual escapade. The project was funded by USAID and the Embassy of Sweden to Tirana and implemented by Creative Business Solutions through IntoAlbania Project. " Another critical point of Onufri Museum is the automation process making it possible that the museum staff have more time and resources to focus on visitors by providing better content and online presence.

In the framework it should be mentioned that the most relevant and sustainable effort that was done so far was to establish an online archive of National Museum of Photography: Marubi. Until now the online archive counts 100,.000 images available for users, around 20\% of the photography material of the Marubi National Museum of Photography archive. The digitalization work is ongoing and is needed to progress further.

According to Ministry of Culture (2019) about $43 \%$ of the national network of museums ( 9 of 21) are visited by 124646 local and foreign tourists. The most visited museum is ranked George Kastrioti- Skanderbeg Museum (with approximately 55,000 visitors) dedicated to our national hero who fought against the Ottoman invasion and in second place is the National History Museum (with approximately 
38,318 visitors). The Ministry of Environment \& Tourism stated that a total of 4 million tourists have visited Albania in 2019, a years before the pandemic Covid 19 and referring the above mentioned statistic on visitors to museums only a total of less than $5 \%$ of them have used museums for cultural tourism purposes(126,646 of 4 milion) . It should be noted that there is a sort of "typological monotony" on the national museums where four are archeological or $30 \%$ of the total number located in Durres, Korca, Fier, Saranda, three or $23 \%$ of them are historical character located in Tirana, Kruja Vlore), three others or $23 \%$ are art museums (Tirana, Korca, Berat) ,two or $16 \%$ are ethnographic (Kruja, Berat) and one or $8 \%$ is on education located in Korca. In this context a set of several initiatives which have recently undertaken can enrich the museum landscape typology quantity, and cultural market development within the country. The above-mentioned opportunities have a positive side as they promote the development of cultural tourism in Albania but on the other hand carry risks to adapt to the increasingly changing environment (UNESCO, 2010). It faces the main challenge of adapting of adapting digital tools, that can offer an interesting cultural package compared to physical collections and use all the potential to attract tourists. All national museums must generate specific information describing their collections, as well as details of events, facilities, services, exhibitions, and resources. Such information, published on the Internet, helps people to visit them. Digital museums remain a challenge not only in our country but also in Europe, e.g., in 2015 museums have only 24\% of their collections exhibited digitally (Nauta, G. \& Wietske, H. 2015).

The "digital gap" of Albania national museums promotion can be overcome by an active promotion campaign. Off-line or on-line promotions of national museum network must assess the previous number of tourists at their sites, as well as the diversity of activities provided in these museums during the holiday seasons. As a need assessment and gap promotion analysis of Albania's national museums, they must confront with the high demand of requests from domestic and foreign visitors, year by year. This challenge could shed the light on a lot of potential to transform identified challenges and gap into opportunities.

\section{Conclusion and Discussion}

The increasing number of digitalized museums and different on-line accessibility tools to access their best collections ever has essentially transformed the way how museums are promoting their values and attracting visitors. As EU Commission stated in a policy brief '...The digital environment likewise has changed the behavior of museum visitors in a fundamental way. Users now expect to be able to actively participate and interact with art on the premises of the museum and online. Participatory behavior (e.g., selfies with objects, tweets) should be encouraged as much as possible within the limits of the law, not discouraged. "(European Policy, 2016). So, the main reason to digitize the museum collections and having them on-line are to enhance access and improve preservation. By increasing number of the museums 
with a higher on-line accessibility, it can make their information accessible across over the world and raise the interest of culture tourist to mark the country as a potential tourist destination. In that case an ICT issue is also seen strongly linked with a public policy approach which want to promote the national heritage and help the local economy. Although an evaluation process must precede any digitization projects regarding the museums since it should move beyond easily quantifiable figures and attempt to determine program's impact on the user. Meanwhile the digitalizing process of the museums is also strongly related with the fact that technology opens new ways for museums to play an important role in research/educational development. Regarding the fact that digitalization is a relatively new term, institutions should focus on goal setting before deciding on the technological tools they will use. The first step is to define the aim and then the technological tools that serve to fulfill this aim. In the case of our country, setting a goal would help us overcome the digital gap. Presenting 500, 1000 or even 100,000 images digitally have no value if their quality is low or not interesting to the public.

Another challenge is that these projects are also very expensive, and so far, no institution has been able to make digitization projects cost effective and attempts to extract costs through user tariffs have not been successful. The costs of digitalization continue even after the completion of a project, as all digital files require maintenance to ensure their well-being in the future. However, despite the challenges or doubts, it is almost certain that the importance of digitalization and online access to museums will increase exponentially in the future and Albania must make its choice to face it like other countries of the EU and beyond.

\section{Bibliography}

[1] Antalony, R. 2013. Managing Intellectual Property for Museums. World Intellectual Property organization (WIPO), retrieved by: https://www.wipo.int/publications/en/details.jsp?id=166

[2] Bandle, A., Benhamou, Y., Burkhaler, S., Ferland, J., Guibault , L., Heaton, M., Logeais, E. Renold, M. \& Sykora, S. (2020) Policy Paper : On the digitalization of Museum Collections, 'Art Law Center, University of Geneva, Swiss Institute for Art Research, retrieved https://www.digitizationpolicies.com/medias/Policy-Paper-on-Digitizationof-Collections.pdf

[3] Clough, W. G. 2013. Best of Both Worlds : Museums, Libraries and Archives in Digital Age, Smithsonian Institutions, ISBN: 978-0-9819500-1-3, retrieved by:

https://www.si.edu/sites/default/files/about/bestofbothworldssmithsonia n.pdf 
[4] Decision of Council of Ministers, No.775. 2005. On the competences, structure, function and manner of meeting and members fee payment of the State Commission of Museums. Official Journal, No.98.

[5] European Commission. 2011. Recommendation on the digitization and online accessibility of cultural material and digital preservation. Official Journal of European Union - OJEU, retrieved by: https://eur-lex.europa.eu/legalcontent/EN/TXT/PDF/?uri=CELEX:32011H0711\&from=EN

[6] International Council of Museums (ICOM). 2017. International Council of Museums (ICOM): As amended and adopted by the Extraordinary General Assembly. retrieved by: https://icom.museum/wpcontent/uploads/2018/07/2017_ICOM_Statutes_EN.pdf

[7] Law 27. 2018. "On the culture heritage and museums. Official Journal, No.86.

[8] Nauta, G. \& Wietske , H. 2015.Survey Report on Digitization in European Cultural Heritage Institutions. Europeana/Enumerate. Retrieved by: http://enumeratedataplatform.digibis.com/reports/survey-report-ondigitisation-in-european-cultural-heritage-institutions-2015/detail

[9] Navarrete, T. (2020) Digitization in Museums. In A. M. Trine Bille, Teaching in Cultural Economics (pp. 204-213). Cheltenham: Edward Elgar Publishing.

[10] UNESCO. 2010. The Transformation of the National History Museum in Tirana. Recommendations and Proposed Next Steps. retrieved by: http://unesdoc.unesco.org/images/0018/001876/187628e.pdf 